\title{
Bimodal assessment to facilitate accurate mediastinal repositioning following pneumonectomy
}

\author{
James Kimpton, ${ }^{1}$ Elaine Teh, ${ }^{1}$ Lucy Cogswell, ${ }^{2}$ Elizabeth Belcher ${ }^{1}$
}

${ }^{1}$ Department of Thoracic Surgery, Oxford University Hospitals NHS Trust, Oxford, UK

${ }^{2}$ Department of Plastic and Reconstructive Surgery, Oxford University Hospitals NHS Trust, Oxford, UK

\section{Correspondence to} James Kimpton, james.kimpton@gtc.ox.ac.uk

Accepted 30 May 2015

CrossMark

To cite: Kimpton J, Teh $\mathrm{E}$, Cogswell L, et al. BMJ Case Rep Published online:

[please include Day Month

Year] doi:10.1136/bcr-2015211190

\section{DESCRIPTION}

We present a case with a successful use of mixed silicone and saline implant expanders to achieve mediastinal repositioning facilitated by periprocedural bimodal assessment. A 63-year-old man with a large central tumour underwent right pneumonectomy. He developed stridor with dyspnoea 3 months later. Clinical and radiological findings were consistent with postpneumonectomy syndrome (figure $1 \mathrm{~A}, \mathrm{~B}) .^{1}{ }^{2}$
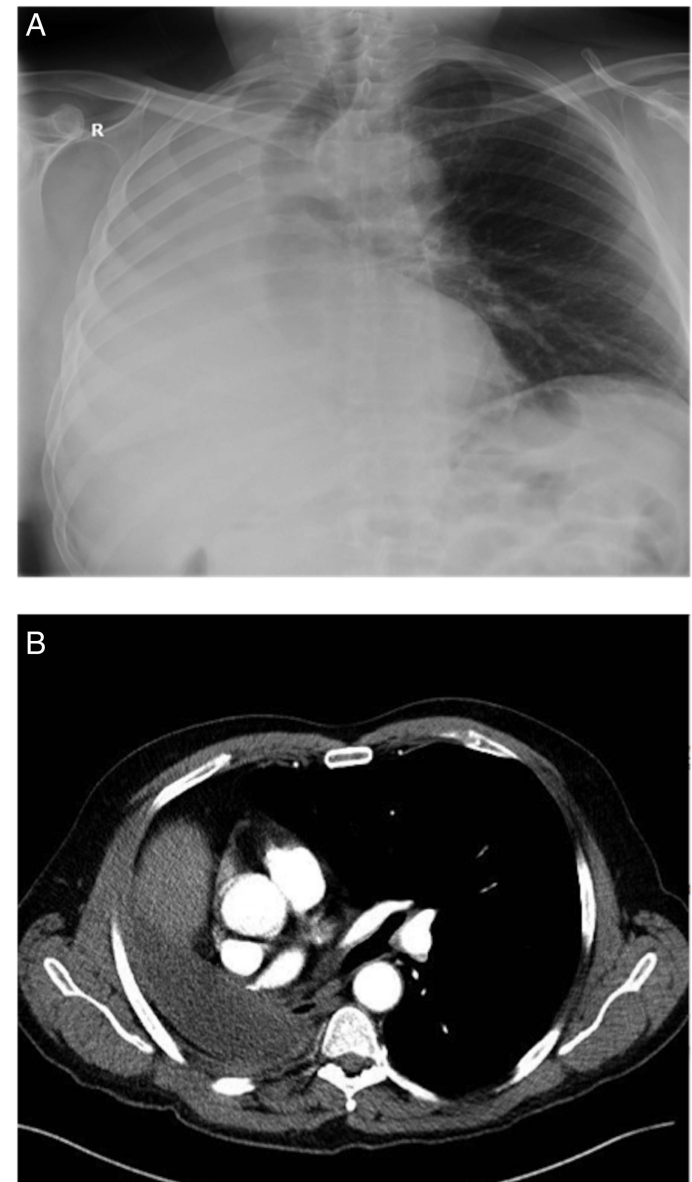

Figure 1 (A) Chest radiograph premediastinal repositioning showing right-sided mediastinal shift. (B) CT scan of the chest showing marked mediastinal shift with arching of the left main bronchus over the descending thoracic aorta.
Mediastinal repositioning was undertaken through the placement of silicone and saline-filled prostheses at rethoracotomy. Intraoperative bronchoscopy was performed to facilitate centralisation of mediastinum. Subcutaneous ports and early CT scanning allowed assessment of positioning. Postoperative imaging (figure 2A, B) confirmed centralisation of mediastinum. This resulted in significant and durable symptomatic relief.
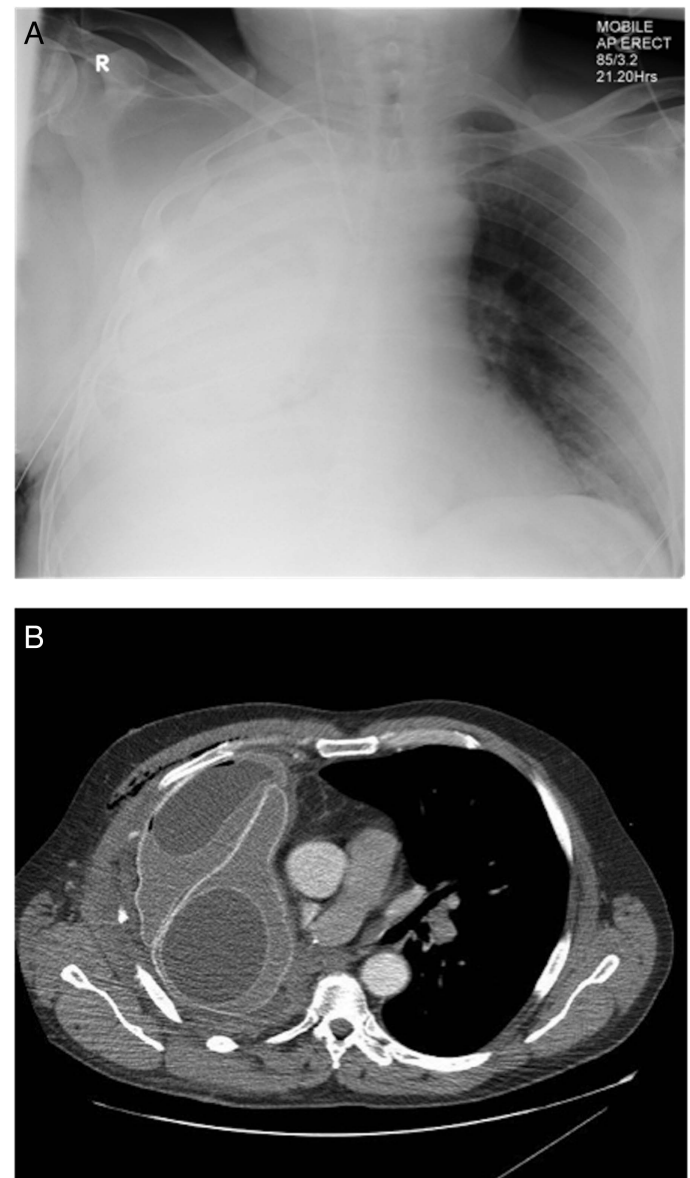

Figure 2 (A) Chest radiograph postmediastinal repositioning showing resolution of the mediastinal shift. (B) CT scan of the chest postmediastinal repositioning demonstrating restoration of the mediastinum to the midline via placement of two silicone and saline breast implants into the right pleural cavity. 


\section{Learning points}

- Postpneumonectomy syndrome should be considered in patients presenting with dynamic airway obstruction following previous pneumonectomy.

- Radiological imaging is characterised by marked mediastinal shift with arching of the main bronchus across the descending aorta or thoracic vertebrae.

- The use of mixed silicone and saline implants facilitates accurate mediastinal repositioning that may be assessed intraoperatively by bronchoscopy.

- Placement of ports in a subcutaneous position enables the surgeon to make further adjustments postoperatively by instillation or removal of saline guided by early postoperative CT scanning.
Contributors JK, ET and EB conceived the idea and wrote the manuscript. LC and EB performed the operation. EB and LC were involved in the preoperative and postoperative patient care. All the authors approved the final manuscript. JK and EB are guarantors.

Competing interests None declared.

Patient consent Obtained.

Provenance and peer review Not commissioned; externally peer reviewed.

\section{REFERENCES}

1 Grillo H, Shepard J, Mathisen D, et al. Postpneumonectomy syndrome: diagnosis, management, and results. Ann Thor Surg 1992;54:638-51.

2 Shen K, Wain J, Wright C, et al. Postpneumonectomy syndrome: surgical management and long-term results. J Thor Cardiovasc Surg 2008;135:1210-16.

Copyright 2015 BMJ Publishing Group. All rights reserved. For permission to reuse any of this content visit http://group.bmj.com/group/rights-licensing/permissions.

BMJ Case Report Fellows may re-use this article for personal use and teaching without any further permission.

Become a Fellow of BMJ Case Reports today and you can:

- Submit as many cases as you like

- Enjoy fast sympathetic peer review and rapid publication of accepted articles

- Access all the published articles

- Re-use any of the published material for personal use and teaching without further permission

For information on Institutional Fellowships contact consortiasales@bmjgroup.com

Visit casereports.bmj.com for more articles like this and to become a Fellow 